\title{
Statü Tüketiminin Fiyat Duyarlılığına Etkisini Belirlemeye Yönelik Bir Araştırma
}

\section{A Research on Determining the Effect of Status Consumption on Price Sensitivity}

\section{Dr. Öğr. Üyesi Polat CAN ${ }^{1}$}

Başvuru Tarihi: 13.06.2018

Kabul Tarihi: 18.02.2019

\section{Öz}

Birey kendisi için anlam ve değeri yüksek olan öğeleri toplum içerisinde ifade etmek ve iletmek için çeşitli işaret ve simgeler kullanmaktadır. Bu bağlamda, günümüzde ise özellikle refah seviyesi olarak gelişmiş ülkelerde tüketici, statüsünü gösteren ürünleri satın almayı tercih etmektedir. Statü tüketimi, tüketicinin otorite kazanmak için başkalarının önem verdiği ve statülerinin göstergesi olan ürünleri satın alıp diğerlerine karşı toplumsal konumlarını güçlendirmeye yönlendirilen motive edici süreçtir. Statüsüne uygun satın alım yapan tüketici için ürünün kalite ve işlevselliğinden çok satın aldı̆̆ı fiyat önemlidir. Bu çalışmada, statülerine uygun alışveriş yapan tüketiciler açısından, statü tüketiminin fiyat duyarlılı̆̆ına olan etkisi belirlenmeye çalışılmıştır. Bu amaç doğrultusunda Uşak il merkezinde yaşayan devlet memurlarına anket uygulanmıştır. Verilerin analizinde, frekans dağılımı, güvenilirlik analizi, aritmetik ortalama, standart sapma, doğrulayıcı faktör analizi ve yapısal eşitlik modelleme (path) analizi kullanılmıştır. Analizler sonucunda, statü tüketiminin tüketici ilgilenimi, tüketici yenilikçiliği ve marka bağgllı̆̆ üzerinde etkili olduğu belirlenmiştir. Tüketici yenilikçiliği ile marka bağlılı̆̆ının fiyat duyarlılı̆̆ı üzerinde etkisi tespit edilirken tüketici ilgileniminin fiyat duyarlılı̆̆ görülmüş̧ür.

Anahtar Kelimeler: Tüketici Davranışı, Statü Tüketimi, Tüketici İlgilenimi, Tüketici Yenilikçiliği, Fiyat Duyarlıliğı

\begin{abstract}
An individual uses various signs and symbols to express and convey items which have meaning and value for him or her in society. In this context, today, especially in the developed countries, the consumer prefers to buy products that are indicative of his or her status. Status consumption is the motivating process in which the consumer is directed towards strengthening his or her social position against others by purchasing products that are important to others in order to gain
\end{abstract}

\footnotetext{
${ }^{1}$ Uşak Üniversitesi İletişim Fakültesi, polat.can@usak.edu.tr, ORCID: 0000-0002-5417-970X
} 
authority. For consumers making purchases in accordance with their status, the price they purchase is much more important than the quality and functionality of the product. This study tried to determine the effect of consumption of status on price sensitivity in terms of consumers who are purchasing statutory goods. For this purpose, a questionnaire was applied to the civil servants living in Ușak city center. In the analysis of the data, frequency distribution, reliability analysis, arithmetic mean, standard deviation, confirmatory factor analysis and path analysis were used. As a result of analysis, it has been determined that consumption of status has an effect on consumer interest, consumer innovation and brand loyalty. It has been seen that consumer interest has no effect on price sensitivity while the effect of consumer innovation and brand loyalty on price sensitivity has been determined.

Keywords: Consumer Behavior, Status Consumption, Consumer Invovement, Consumer Innovativeness, Price Sensitivity

\section{Giriş}

Tüketici birçok farklı nedenden dolayı alışveriş ve satın alımlarını gerçekleştirmektedir. Bu nedenler, rasyonel olabileceği gibi sosyal statüsünü gösteren hedonik ihtiyaçlarını karşılamak içinde olabilmektedir (Iyer vd., 2017, s.50). Tüketicinin sosyal statüsünü gösteren ürünlere karşı ilgisi artmakta ve satın alımlarında bu tarz ürünleri tercih etmektedir (Amaldoss ve Jain, 2005, s.1453; Charles vd., 2009, s.428). Bu durum ise, işletmelerin ürün ve marka stratejisi oluştururken statü tüketimi kavramına odaklanmasına neden olmaktadır (Wetlaufer, 2001, s.118; Gardyn, 2002, s.32; Han vd., 2010, s.18).

Pazarlama alanında statü tüketimi konusunda çok fazla çalışmaya rastlanmaktadır. Yapılan çalı̧malar daha çok statü göstergesi olan ürünler için tüketicinin neden daha fazla ödeme yaptığıyla ilgili sosyolojik ve ekonomik teorilere dayanmaktadır (Gao vd., 2016; Iyer vd., 2017). Statü tüketimi ve fiyat duyarlıllğını ayrı ayrı ele alan araştırmalar mevcuttur, ancak bu iki değişkeni birlikte ele alan ve aralarındaki ilişkiyi inceleyen bir çalışmaya rastlanmamıştır. $\mathrm{Bu}$ çalışmada, statü tüketiminde etkili olduğu düşünülen ilgilenim, yenilikçilik, marka bağlllığı ve fiyat duyarllığı gibi faktörler incelenecek ve psikolojik boyutlu araştırma boşluğunun azaltılması sağlanacaktır.

Yüksek marka statüsü genellikle yüksek fiyatlandırma için bir gerekçe olarak kullanılmaktadır. İşlemeler, tüketicilerin statülerinin göstergesi olan markaları satın almak için daha fazla para ödemelerini beklemektedir. Bununla birlikte, bu ilişkinin nasıl oluştuğu inceleyen çok fazla çalışmaya rastlanılmamaktadır. Bu çalışmada, statü tüketiminin giyim sektöründe marka bağlllığı olanların, statü kazandırabileceği düşüncesiyle tüketici katılımını, yenilikçiliği ve marka sadakatini artırdığı düşünülmektedir.

Yüksek düzeyde katılım, yenilikçilik ve marka sadakati gösteren tüketicinin satın almayı düşündüğü markanın fiyatının yüksek olmasına dikkat etmeyip satın almaya istekli olduğu markayı tercih etmektedir. Statü tüketiminin daha çok giyim, otomobil, oturulan ev, cep telefonu gibi ürün gruplarında etkili olduğu görülmektedir. Buradan hareketle, çalışmada 
statünün satın alımlarda önemli rol oynadığı ürün kategorisi olarak giyim kullanılmıştır. Çalışma iki kısımdan oluşmaktadır. İlk bölümde statü tüketimi, tüketici katılımı, yenilikçilik, marka bağlılığı ve fiyat hassasiyeti ile ilgili kavramsal çerçeve incelenmiştir. İkinci bölümde ise, statü tüketiminin fiyat hassasiyeti üzerindeki etkisini ölçmeye yönelik araştırma sonuçlarına yer verilmiştir.

\section{Kavramlar ve Hipotezler}

\section{Statü Tüketimi}

Başlangıçta, gösterişçi ve statü tüketimi birbiriyle karıştırılmakta ve çoğu zamanda birbirlerinin yerine kullanılmaktaydı. Zaman içerisinde, gösterişçi tüketiminin doğası gereği materyalist unsurların, statü tüketiminde ise bireyin sosyal yapı içerisindeki konumunu gösteren satın alma eyleminin öne çıktığı görülmüştür (Kwon ve Kwon, 2013, s.120). Bununla birlikte, daha sonra O'Cass ve McEwen (2004) tarafından yapılan çalışmada bu tüketim yapılarının ampirik olarak da farklı olduğu görüşü ileri sürülmüştür. Gösterişçi tüketimin temelini, lüks ürün ve hizmetlerin tüketilmesi ile maddi zenginliğin sergilenmesi oluşturmaktadır (Trigg, 2001, s.101). Statü tüketimi ise, bireyin toplum içerisindeki konumunu gösteren ürün ve hizmetleri satın almayı tercih etmesidir (Sundie vd., 2011, s.667).

Statü tüketimi, saygıdan oluşan gücün sergilenmesi için, satın alımların bu doğrultuda şekillenmesi ve toplum içerisinde elde edilen statü ayrıcalığının tüketime yansımasıdır (Sundie vd., 2011, s.669 ). Bir diğer ifadeyle statü tüketimi, "kişilerin statü sembolü olan ürünleri çevrelerindeki kişilere konumlarını göstermek amacı ile satın almalarına neden olan motivasyonel bir süreç” olarak tanımlanabilir (Aslay vd., 2013, s.45). Bireyi statü tüketimine yönlendiren motivasyonel güç, kültürel normlar, referans grupların beklenti ve kurallarınca şekillenmektedir (Segal ve Podoshen, 2013, s.191). Bu nedenle, toplum içerisinde sahip olduğu statüye uygun satın alım yapmak isteyen tüketici, bunu gösteren ürünleri satın alımlarında tercih etmektedir. Çünkü satın alımlarında yönlendirici unsur sadece ihtiyacı değil, aynı zamanda örnek aldığı referans gruptur (Clark vd., 2007, s.48). Bu bağlamda statüsünü topluma göstermek isteyen tüketici, sadece ihtiyaçlarını karşılamak için alışveriş yapmamakta benzer statüye sahip olanların sergilediği görüntüye sahip olmak için alışveriş yapmaktadır. Dolayısıyla statü tüketimi fiziksel ihtiyacı karşılamak amacıyla değil başkalarını etkilemek ve diğerleri üzerinde otoriteye sahip olmak içinsergilenen tüketici davranışı olarak görülmektedir (Eastman ve Liu, 2012, s.95).

Sosyologlar, sosyal konuma olan arzunun, toplumsal hiyerarşide üst düzeyde yer alma isteğinin yani toplum içerisindeki statünün bireyin davranışlarının şekillenmesinde güçlü bir motivasyon kaynağ olduğunu belirtmektedirler (Sundie vd., 2011, s.670; Schimpfossl, 2014, s.66; Eastman ve Eastman, 2015, s.763). Buradan hareketle bazı pazarlama araştırmacıları statü tüketiminin, ürün ve özellikle marka seçiminde önemli bir yönlendirici olduğunu vurgulamaktadır (Tsai, 2005, s.432; Shukla, 2010, s.113; Nelissen ve Meijers, 2011, s.347). Ayrıca, artan ekonomik refah seviyesi tüketicilerin harcanabilir gelirlerinin yükselmesini sağlamakta ve bu durum fiyatı yüksek ve toplumsal statünün göstergesi olan ürün ve markalara 
ilginin artmasına neden olmaktadır (Heffetz, 2011, s.1104). Chao ve Schor (1998) yaptıkları çalışmada ilk olarak statü tüketimini ürün gruplarına göre farklılık gösterip göstermediğini incelemişler ve kadınların özellikle kozmetik ürün grubunda statülerini öne çıkaran ürünleri tercih ettiklerini tespit etmişlerdir. O’Cass ve Frost (2002) statü tüketiminde markanın etkisini araştırmışlar ve giyim sektöründe statü tüketimin daha çok öne çıktığını tespit etmişlerdir. Buna benzer bir çalışmada Goldsmith vd. (2010) benzer şekilde statü tüketiminin fiyat hassasiyeti üzerindeki etkisini incelemişler ve bu etkinin söz konusu olduğunu bulmuşlardır.

Eastman vd. (1999) yaptıkları çalışmada statü tüketimi ile materyalizmin farklı olduğu görüşünden yola çlkarak statü tüketimini ölçmek için ölçek geliştirmek istemişlerdir. Bu görüş doğrultusunda tüketicilerin toplum içerisinde çekici görünmek istediklerini belirtmişlerdir. Çalışmanın sonucunda ise, bu tüketicilerin başkalarının düşüncelerine önem verip statülerini gösterdiklerine inandıkları ürünlerin fiyatının yüksek olmasına rağmen satın almak için istekli oldukları tespit edilmiştir. Coopers (2012) ise ürün gruplarına göre satın alım farklılıklarında etkili olan unsurları incelemiş ve toplum içerisinde statüsünü öne çıaran ürünleri tercih eden tüketiciler için fiyatın yüksek olmasının önemli olmadığı sonucunu elde etmiştir.

Cronje vd. (2016), 24 ve 36 yaş arasındaki tüketiciler üzerinde yaptıkları araştırmada giyim sektöründe marka bağlılı̆̆ının statü tüketimin şekillenmesi ve satın alım davranışının bu doğrultuda oluşmasında yönlendirici etkisinin olduğu sonucuna varmışlarıdır. Gao vd. (2016), çalışmalarında tüketici katılımının statü tüketimindeki ilişkisini incelemişlerdir. Buradan hareketle, statü tüketiminin; tüketici katılımı, marka bağlılığı ve tüketici yeniliği üzerinde etkisinin olduğu ve bunlarında fiyat hassasiyetini etkilediği düşülmektedir.

\section{Tüketici IIIgilinim}

İlgilinim, tüketici davranışları alanında bilinen ve yaygın olarak incelenen kavramlardan biridir. $\mathrm{Bu}$ kadar çok incelenmesinin sebepleri arasında tüketicinin ürüne olan ilgileniminin heves, istek ve heyecan gibi psikolojik özelliklere dayanmasıdır (154edia154 Jia, 2016, s.1188). Ürünün fiyatının yüksek olması, çok sık 154edia alınmaması ve ürünün karmaşık yapıya sahip olması gibi nedenler yüksek tüketici ilgilenimini gerektirmektedir. Buna karşılık, sık 154edia alınan, düşük fiyatlı, karar verme aşamasının basit olduğu ürünlerde ise düşük ilgilenim söz konusudur (Borgogno vd., 2015, s.140). Ancak, cep telefonu, kozmetik, giysi gibi toplum içerisinde farklılığı sağlayan ürünlere de tüketicinin ilgilenim seviyesi yüksek olmaktadır (Assael, 2004, s.249).

Goldsmith vd. (1996) statü tüketiminin giyim ilgilenimi ile ilişkili olduğunu öne sürmüşlerdir. Çünkü statü tüketimine önem veren tüketicilerin, kıyafet konusunda bilgili oldukları ve bu bağlamda bazı giyim markalarını statülerini sergiledikleri için tercih ettiklerini belirtmişlerdir. Flynn vd. (2016) ise, tüketicinin toplumda statüsünü yansıtan giysi alırken karar aşamasında daha dikkatli ve seçici olduğu sonucuna ulaşmışlardır. 
$\mathrm{Bu}$ çalışmada statü tüketiminin, giysi ilgilenimine olan etkisi araştırılacaktır. Buna göre araştırmanın ilk hipotezi şu şekilde oluşturulmuştur:

$\mathrm{H}_{1}$ : Statü tüketimi tüketici ilgilenimini etkilemektedir.

Lertwannawit ve Mandhachitara (2012), tüketici giysi 155edia alırken yoğun bilgi arayışında olduğunu, mağaza değerlendirmesine önem verdiğini, bilinen markaları tercih ettiğini ve alışveriş esnasında rahat ve huzurlu alışveriş ortamına dikkat ettiğini belirtmiştir. Wang ve Griskevicus (2014), kadınların erkeklerden daha fazla giysi 155edia alımları ile ilgilendiğini ve uygun fiyatlı olanı bulmak için yoğun çaba sarf ettiklerini ifade etmektedirler. Chen ve Kim (2013) yaptıkları çalışmada, giysi 155edia alımlarında tüketicilerin katalog, sosyal 155edia, internet gibi bilgi kaynaklarını fiyat araştırmasında kullandıklarını ortaya koymuştur. Ramirez ve Goldsmith (2009), tüketiciler üzerinde giysiye olan ilgilenimin artmakla birlikte moda ve yenilik gibi faktörlerin düşük fiyattan daha fazla etkiye sahip olduğunu belirtmişlerdir. Buradan aşağıdaki hipotezler şu şekilde kurulmuştur.

$\mathrm{H}_{2}$ : Tüketici ilgilenimi fiyat duyarlılığını etkilemektedir.

Tüketici katılımı araştırmalarının merkezini çoğunlukla, ürün kategorisine olan ilgi, istek, fiyat duyarlılığı ve tüketici eğilimleridir. Ancak, son zamanlarda yapılan çalışmalarda ürün kategorisindeki fikir liderliği ve özellikle tüketici yenilikçiliği de dikkat çekmektedir (Brockhoff, 2003, s.465; Lin vd., 2013, s.316; Alves vd., 2016, s.70). Dubois vd., (2012), ürün kategorisine ilgi duyantüketicinin, ilgi alanında olan ve pazara yeni çıkan ürünleri araştırıp bilgi edindiğini belirtmektedir. Ayrıca, Ürün grubu hakkında hevesli olduğunu ve bu nedenle en yeni ürünleri tercih ettiklerini söylemektedir. Bu bağlamda, ürün kategorisine olan katılımın tüketici yenilikçiliği ile pozitif olarak ilişkili olduğu bildirilebilir. Bu nedenle, şu şekilde hipotez incelenebilir;

$\mathrm{H}_{3}$ : Tüketici ilgilenimi tüketici yenilikçiliğini etkilemektedir.

\section{Tüketici Yenilikçiliği}

Raskovic vd., (2015), yenilikçiliği bireyin içinde bulunduğu sosyal ortamda yeni fikir ve düşünceleri benimse konusunda diğerlerinden daha erken hareket etme derece olarak tanımlamaktadır. Bartels ve Reinders (2011) ise, bireyin teklik ve sosyal tanınmayla ilişkin psikolojik gereksiniminin yenilikçilik açısından önemli bir rol oynadığını ifade etmektedirler. Tüketici davranışları açısından ise yenilik, pazarlama karmasının hedef pazar tarafından yeni olarak algılanması ve kabul edilmesidir (Mishra, 2015, s.37). Bu bağlamda, tüketicilerin yeniliğe olan tepkilerini anlamak, açıklamak ve tahminde bulunmak pazarlamacılar açısından büyük önem taşımaktadır. Çünkü yeni sunumların başarısı tüketicinin bunu benimsemesi ile ilişkilidir.

Tüketici yenilikçiliği, tüketiciyi pazardaki yeni tekliflerin ilk alıcıları arasında yer almaya yönlendiren ve motive eden yeni ürünlere yönelik ilgi durumudur. Neredeyse bütün ürün kategorileri, yeni ürünler arayan ve bunları satın almak için istekli azınlık bir alıcı grubuna sahiptir (Hong vd., 2016, s.267). Bu erken hareket edenler, ürünü sık kullanıcısı olmak, ürün 
kategori hakkında detaylı bilgiye sahip olmak, ürün hakkında süreli araştırma yapmak ve fikir lideri olmak gibi ortak olan özellik ve davranışlar sergilemektedirler. Ayrıca, yeni ürünlere ilk sahip olunması tüketici için prestij elde etmenin motivasyon kaynağı olarak görülmekte ve bu durum sosyal statüyle ilişkilendirilmektedir (Morton vd., 2016, s.19). Naehyun vd., (2016), yüksek sosyal konuma sahip olunmasının yeni ve farklı ürünlerin denenmesinde öne çıkan unsurların başında geldiğini belirtmiştir. Mishra (2015) ise yeni ürünlere sahip olmak isteyenlerin, yüksek harcanabilir gelire sahip olduklarını ve diğer tüketicilerden farklı olmak istedikleri ifade etmiştir. Buradan hareketle $\mathrm{H}_{4}$ hipotezi şu şekilde geliştirilebilir;

$\mathrm{H}_{4}$ : Statü tüketimi tüketici yenilikçiliğini etkilemektedir.

Goldsmith vd. (2010), satın alma davranışı ve kişisel özellikleri benzer olan bireylerin sergiledikleri tüketici yenilikçiliğinin fiyat hassasiyetine etkisinin olup olmadığını incelemiş̧ler ve ürün kategorisine göre farklı yenilikçilik davranışları sergilediğini belirtmişlerdir. Wingfield (2005), video oyun meraklıları üzerine yaptığı çalışmasında, tüketicilerin yüksek fiyatın en son versiyon oyunları takip etmelerine engel olmadığını sonucuna varmıştır. Munnukka (2005), mobil hizmet müşterilerinin yenilik ile fiyat duyarlılığı arasında önemli ölçüde ilişki olduğunu bulmuştur. Hussain ve Rashidi (2015), restoran müşterileri üzerine yaptığı araştırmada, tüketici yenilikçiliği ile fiyat duyarlılığı arasında negatif bir ilişkinin olduğunu belirtmiştir. Son olarak, birçok çalışma moda ve fiyat arasında ilişkiyi tespit etmiştir (Clark vd., 2007, s.55; Dmitrovic vd., 2009, s.531; Tellis vd., 2009, s.18; Bartels ve Reinders, 2011, s.607). Yukarida incelenen çalışmalar neticesinde $\mathrm{H}_{5}$ hipotezi şu şekilde geliştirilmişstir;

$\mathrm{H}_{5}$ : Tüketici yenilikçiliği fiyat duyarlılı̆̆ını etkilemektedir.

Tüketici yeniliği ve marka bağlılı̆̆ iki önemli konu olmasına rağmen aralarındaki ilişkiyi inceleyen çok az çalışmaya rastlanmaktadır. Tanımı gereği yenilikçilik, çeşit arama ve yeni şeylerle ilgilenmedir. Tüketici yenilikçiliği, doğası gereği yeni ve farklı olma isteğinden dolayı yeniliği daha sonra benimseyenlere kıyasla daha az marka bağlılığı olan tüketicilerde olması söz konusudur (Bin, 2013, s.611). Bununla birlikte, yenilikçiler ilgi duyan, hevesli ve ürün kategorisi hakkında bilgili tüketicilerdir. Bu nedenle, en son ürünleri araştırıp bulmak ve ilk satın alanlar arasında olmak istemektedirler. Şayet bu yeni ürünler, tanıdıkları ve kullandıkları markalardan geliyorsa bağlllı̆̆ı etkilemesi söz konusu olabilir (Yun ve Hira, 2012, s.280).

Kotler (2000), işletmelerin uzun süreli olabilmesi için ürün yeniliğinin önemli bir unsur olduğunu ileri sürmektedir. Çünkü yenilikçi tüketicilerde oluşturulacak marka bağlllğ̆ı ve uzun vadeli ilişkileri teşvik edebilecektir. Giyim sektöründe, bazı marka isimleri yenilikçi ve öncü moda tasarımlarıyla ilişkilendirilmekte ve bu durum yeni moda kıyafetleri erken benimseyenler içinyaşadığı ortamda moda lideri imajını oluşturmakta ve markaya sadakatine yol açabilmektedir (Roehrich, 2004, s.673). Başka bir deyişle, modayı takip eden tüketiciler markaya sadık kalıp tasarım ve stil boyutuyla yenilikçi olabilirler (Alves vd., 2016, s.74). Cronje vd., (2016) bu düşünceyi desteklemek için, giyim yenilikçiliği ve bilişsel marka sadakati arasında pozitif bir ilişki olduğunu bildirmişlerdir. Böylece aşağıdaki hipotez geliştirilmiştir;

$\mathrm{H}_{6}$ : Tüketici Yenilikçiliği marka bağlllı̆̆ını etkilemektedir. 


\section{Marka Bağlılığı}

Tüketiciler genellikle satın aldıkları ürün ve özelliklede marka ile kendi kişiliği ve sosyal konumu arasında ilişki kurmakta ve geliştirmektedir. Bu geliştirilen ilişki ise, satın alma sıklı̆̆ ve tutumsal sadakat ile zaman içerisinde marka bağlılığının oluşmasına neden olmaktadır (Aaker, 1991, s.2). Marka bağlılığı, pazarlama yönetiminin en çok önem verdiği hedeflerden birini oluşturmaktadır. Çünkü marka bağlılığı, marka değerinin önemli bir bileşeni olması nedeniyle müşteri maliyetlerinin düşük olmasını sağlamaktadır (Minton vd., 2016, s.369). Marka bağlılığı hakkında çok fazla çalışma olmasına rağmen statü tüketimi ve fiyat duyarlılığ ile marka bağlılığı arasındaki ilişkiyi inceleyen çok az çalışmaya rastlanmaktadır. Özellikle, marka bağlılı̆̆ ile fiyat duyarlılığ 1 arasındaki ilişki, tüketicilerin ödemeye istekli olduğu bedelin anlaşılması açısından önemli olmaktadır (Mann ve Sahni, 2015, s.183). Park ve Rabolt (2006) belirttikleri gibi, tüketici ürünün fiyat değişiminden haberdardır ancak satın alma davranışında değişiklik oluşturmak için marka bağlılı̆̆ı gibi faktörler öne çıkmaktadır. Fornier (1998) tüketicinin markalarla oluşturduğu ilişkiyi açıklamak amacıyla yaptığı çalışmada, satın alımında statü isteyen tüketicinin, markanın bu statüyü sağladığı sürece bağlılığın arttığını ortaya koymuştur. Gabriel ve Lang (2006), giysinin sosyal ortamda gözle görünmesinden dolayı tüketici statüsünü öne çıkaran markalara karşı bağlandığını belirtmişlerdir. Bu bulgular ışığında sonraki hipotez şu şekilde kurulabilir;

$\mathrm{H}_{7}$ : Statü tüketimi marka bağlılığını etkilemektedir.

Tüketicinin, yüksek bedeline rağmen markalı ürünleri satın almaya istekli olması marka bağlılığının fiyat duyarlılı̆̆ı üzerindeki etkisinin incelenmesi önem kazanmıştır (Phau ve Cheong, 2009, s.113). O’Cass ve Frost (2002), tüketicinin perakendesektöründeki satın alımlarında etkili olan faktörlerin marka ve nicelik olduğunu belirtmektedir. Marka bağl1lı̆g olan tüketicinin bağlı olmayanlara göre daha az fiyata duyarlı olduğunu ancak nicelik söz konusu olduğunda fiyat duyarlılığına daha fazla önem verdikleri görülmüştür. Rahbariana ve Meshkanib (2014), benzer çalışmayı mobil telefeon sektöründe yapmışlar ve marka bağlılığı olan tüketicilerin ürünün fiyatının yüksek olup olmadığına dikkat etmedikleri sonucunu elde etmişlerdir.

Mullarkey (2001)'e göre, giysiye ödenen fiyatın perakende ürünlere ödenenden daha fazla olması giysi satın alımında stil ve imaja perakende ürüne göre daha fazla önem verilmesine neden olmaktadır. Bu nedenle, giyim satın alımlarında marka bağlılı̆̆ uyum, tarz unsurlardan etkilenen karmaşık bir yapıya dönüşmektedir. Bu durumda, marka bağlılığının fiyat duyarlılığı üzerinde etkisinin olduğu söz konusu olmayabilir. Tüketici bağlı olduğu markayla ilgilenir çünkü bu bağlıllk imajına uygun ve toplum içerisinde statüsünü göstermesine yardımcı olmaktadır. Flynn vd. (2000), giyim sektöründe marka bağlılığı ile fiyat duyarlılığı arasında ile negatif korelasyon olduğunu rapor etmektedir. Benzer sonuca Wilson (2006)'da çalışmasında elde etmiş ve denim ürün kategorisinde üniversite öğrencilerinin marka bağlılığı ve fiyat hassasiyet ölçümlerinin negatif korelasyonlu olduğunu bildirmiştir. Lau vd. (2006), üniversite öğrencileri üzerinde yaptıkları araştırmada, giyim markası sadakati ile giyim fiyat duyarlılığı arasında negatif bir ilişki olduğunu bildirmiş ve fiyat odaklı sadık tüketicilerin 
marka değiştirdiklerinde ürünler arasında fark bulamadıklarını belirtmişlerdir. Dolayısıyla, giyim sektöründe markaya bağlı yüksek tüketicilerde fiyata olan duyarlllığın düşük olduğu görülmektedir. Bu durumda aşağıdaki hipotez geliştirilebilir;

$\mathrm{H}_{8:}$ : Marka bağlllığı fiyat duyarlılı̆̆ını etkilemektedir.

Statü tüketimi ve fiyat duyarlılı̆ğ ile ilgili yapılmış araştırmaların incelenmesi sonucu oluşturulan hipotezler çerçevesinde araştırmanın modeli aşağıdaki şekilde oluşturulmuştur.

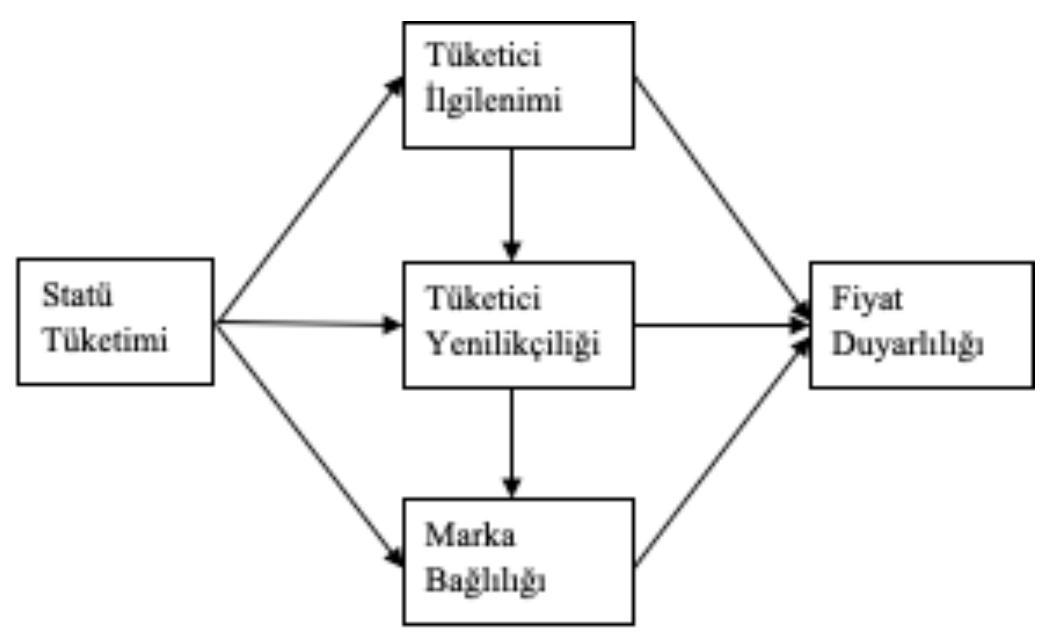

Şekil 1. Araştıranın Modeli

\section{Araştırmanın Yöntemi}

\section{Araştırmanın Metodolojisi}

\section{Ön Çalışma}

Araştırma için kesin anket formu hazırlanıp veri toplanmasına geçilmeden statü tüketimi konusunda daha önce yapılan çalışmalar incelendiğinde ürün grubu olarak çoğunlukla giysi kullanıldığg görülmüş (Goldsmith vd., 2010; Mann ve Sahni, 2015; Cronje vd., 2016; Flynn vd., 2016) ve bu yüzden çalışmada ürün grubu olarak giyim belirlenmiştir. Daha sonra araştırmada kullanılacak anket formu hazırlanmış ancak veri toplama aşamasına geçilmeden önce 20 devlet memuru ile görüşülerek anketle ilgili görüşleri alınmış ve görüşler doğrultusunda anlaşılmayan 8 ifade düzeltilip anket formuna nihai şekli verilmiştir.

\section{Örnekleme Süreci}

Araştırmanın ana kütlesini Uşak il merkezinde yaşayan devlet memurları oluşturmuştur. Araştırma örneklemine, "Giyim alışverişlerinizde statünüze uygun olan giysilerimi tercih edersiniz?” soru sorulmuş ve bu soruya evet cevabı veren tüketiciler alınmıştır. Ana kütlenin standart sapması bilinmediği için, \%95 güven aralığında ve \%5 hata payında araştırmanın örnek büyüklüğü 385 olarak belirlenmiştir. 2-23 Ocak 2017 tarihleri arasında 648 devlet memuruna “Giyim alışverişlerinizde statünüze uygun olan giysilerimi tercih edersiniz?” sorusu yöneltilmiş 
ve bu soruya "evet" cevabı veren 382 kişiye anket uygulanmıştır. Hatalı ve eksik doldurulan 21 anket değerlendirmeye alınmayıp 361 anket araştırma kapsamında değerlendirilmiştir.

\section{Veri Toplama Yöntem ve Aracı}

Araştırmada veri toplama yöntemi olarak anket tekniği ve örnekleme yöntemi olarak kolayda örnekleme yöntemi kullanılmıştır. Anket formu, 2 soru grubundan oluşmuştur. Birinci grup sorular cinsiyet, medeni durum, aylık geliri, eğitim durumu, yaşı ve çalıştığı bakanlık değişkenlerinden oluşan demografik ve ekonomik özellikleridir. İkinci grup sorular ise statü tüketimi, tüketici ilgilenimi, tüketici yenilikçiliği, marka bağlılığı ve fiyat duyarlılığ değişkelerinden oluşmuştur. Statü tüketimi; Eastman vd., (1999), tüketici ilgilenimi; Mittal ve Lee (1989), tüketici yenilikçiliği; Goldsmith ve Hofacker (1991), marka bağlılığ1; Beatty ve Kahle (1988) ve fiyat duyarlılığı; Goldsmith ve Newell (1997) çalışmalarından yararlanılarak hazırlanmıştır. Araştırmanın teorik çerçevesince hazırlanan model, statü tüketimi (5 ifade), tüketici ilgilenimi (3 ifade), tüketici yenilikçiliği (7 ifade), marka bağlılığ 1 (4 ifade) ve fiyat duyarlılığı (5 ifade) olmak üzere 5 değişken ve 24 ifadeden müteşekkildir. İkinci grupta, yer alan ifadelere yönelik cevapların alınmasında 5'li Likert ölçeği (5=Tamamen katılıyorum;1=Kesinlikle katılmıyorum) kullanılmıştır. Veriler SPSS 23,0 ve LISREL 9.1 paket istatistik programları yardımıyla analiz edilmiştir. Verilerin analizinde, frekans dağılımları, güvenilirlik analizi, aritmetik ortalamalar, standart sapmalar, doğrulayıcı faktör analizi ve yol (path) analizi kullanılmıştır.

\section{Verilerin analizi}

Cevaplayıcıların Demografik ve Ekonomik Özellikleri

Tablo 1'de araştırmaya katılan cevaplayıcıların demografik ve ekonomik özellikleri gösterilmektedir. 
Tablo 1. Cevaplayıcıların Demografik ve Ekonomik Özellikleri

\begin{tabular}{|c|c|c|c|c|c|}
\hline Cinsiyet & Frekans & Yüzde & Aylık Geliri (TL) & Frekans & Yüzde \\
\hline Kadın & 202 & 55.9 & $0-1300$ & 18 & 5.0 \\
\hline Erkek & 159 & 44.1 & $1301-2600$ & 86 & 23.8 \\
\hline Medeni Durumu & Frekans & Yüzde & $2601-3900$ & 158 & 43.7 \\
\hline Evli & 322 & 89.2 & $3901-5200$ & 67 & 18.6 \\
\hline Bekâr & 39 & 10.8 & 5201 ve üzeri & 32 & 8.9 \\
\hline Çalıştığı Bakanlık & Frekans & Yüzde & Eğitim Durumu & Frekans & Yüzde \\
\hline Adalet Bakanlığı & 31 & 8.6 & illköğretim mezunu & 9 & 2.5 \\
\hline $\begin{array}{l}\text { Aile ve Sosyal Politikalar } \\
\text { Bakanlığı }\end{array}$ & 17 & 4.7 & Lise mezunu & 32 & 8.9 \\
\hline $\begin{array}{l}\text { Çalışma ve Sosyal Güvenlik } \\
\text { Bakanlığı }\end{array}$ & 15 & 4.2 & $\begin{array}{l}\text { Meslek Yüksekokulu } \\
\text { Mezunu }\end{array}$ & 78 & 21.6 \\
\hline Çevre ve Şehircilik Bakanlığı & 16 & 4.4 & Lisans mezunu & 216 & 59.8 \\
\hline Gençlik ve Spor Bakanlığı & 7 & 1.9 & $\begin{array}{l}\text { Lisansüstü Eğitim } \\
\text { mezunu }\end{array}$ & 26 & 7.2 \\
\hline $\begin{array}{l}\text { Gıda, Tarım ve Hayvancılık } \\
\text { Bakanlığı }\end{array}$ & 13 & 3.6 & Yaş & Frekans & Yüzde \\
\hline İçişleri Bakanlığı & 33 & 9.1 & $18-27$ & 87 & 24.1 \\
\hline Kültür ve Turizm Bakanlığı & 11 & 3.2 & $28-37$ & 119 & 32.9 \\
\hline Maliye Bakanlığı & 14 & 3.9 & $38-47$ & 108 & 29.9 \\
\hline Milli Eğitim Bakanlığı & 101 & 27.9 & $48-57$ & 37 & 10.3 \\
\hline Orman ve Su işleri Bakanlığı & 5 & 1.4 & 58 ve üzeri & 10 & 2.8 \\
\hline Sağlık Bakanlığı & 77 & 21.3 & & & \\
\hline $\begin{array}{l}\text { Ulaştırma, Denizcilik ve } \\
\text { Haberleşme Bakanlığı }\end{array}$ & 21 & 5.8 & & & \\
\hline TOPLAM & 361 & 100 & TOPLAM & 361 & 100 \\
\hline
\end{tabular}

Araştırmaya katılanların \%55.9'u kadın (202 kişi) ve \%44.1'i erkek (159 kişi) dir. Medeni durum açısından ele alındığında, \%89.2'si evli (322) ve \%10.8'i bekâr (39 kişi) dır. Aylık gelir açısından ilk sıraları \%43.7 ile 2601-3900 TL (158 kişi) ve \%23.8 ile 1301-2600 TL (86 kişi) gelir grupları almaktadır. Cevaplayıcıların, \%59.8'i lisans mezunu (216 kişi), \%21.6’sı meslek yüksekokul mezunu (78 kişi) ve \%8.9’u lise mezunu (32 kişi) dur. \%32.9’u 28-37 (119 kişi), \%29.9’u 38-47 (108 kişi) ve \%24.1’i 18-27 (87 kişi) yaş grubundadır. Cevaplayıcının çalıştı̆̆ kurumun bağlı olduğu bakanlık olarak ilk sırada \%27.9 ile Milli Eğitim Bakanlığı (101 kişi), ikinci sırada \%21.3 ile Sağlık bakanlığı (77 kişi) ve üçüncü sırada \%9.1 ile İçişleri Bakanlığı (33 kişi) gelmektedir.

\section{Araştırmada Yer Alan Ölçeklerin Test Edilmesi}

Araştırmanın modelinde yer alan değişkenlerin güvenilirliğini test etmek amacıyla, değişkenin iç tutarlılığını ölçen Cronbach alfa katsayısı yöntemi kullanılmıştır. Bu katsayı, çok ifadeli değişkendeki, ifadeler arasındaki uyumun derecesini gösterir ve 0 ile 1 arasında değer alır. $\mathrm{Bu}$ değer, l'e yaklaştıkça değişkende yer alan ifadeler arasındaki iç uyumun o denli yüksek olduğu söylenebilir (İslamoğlu ve Alnıaçık, 2013, s.278). Modelde yer alan, statü tüketimi ( $\alpha=0.834$ ), 
tüketici yenilikçiliği ( $\alpha=0.826)$, marka bağlılığı ( $\alpha=0.814)$ ve fiyat duyarlılığı ( $\alpha=0.808)$ değişkenlerinin Cronbach alfa değerlerinin yüksek olduğu görülmüştür. Ancak tüketici ilgilenimi değişkende yer alan "GG3: Benim için giyim önemli değildir." ifadesinin soru-bütün korelasyon katsayısının değişkenin Cronbach alfa katsayısından büyük olduğu görülmüş ve bu ifade değişkenden çıkarılıp analiz tekrarlanmış ve tüketici ilgilenimi değişkenin Cronbach alfa katsayısının yeni değerinin 0.788 olduğu tespit görülmüştür.

Araştırma değişkenlerinin güvenilirliklerinin yüksek olduğu görüldükten sonra bunların örneğe uygunluğunu test etmek amacıyla doğrulayıcı faktör analizi yapılmıştır. Analizin ilk aşamasında, tüketici ilgilenimi ve marka bağlılığı değişkenlerinin örnekle mükemmel uyum² sağladığı bulunmuştur. Ancak, statü tüketimi, tüketici yenilikçiliği ve fiyat duyarlılığ değişkenlerinin uyum değerlerinin kabul edilebilir ${ }^{3}$ sınırlar içerisinde yer almadığ 1 görülmüştür. Modifikasyonlar incelenerek Ki-Kare üzerinde en yüksek değerde modifikasyon öneren statü tüketimi değişkeninden "ST5: Giysinin statüsü beni ilgilendirmez” ve tüketici yenilikçiliği değişkeninden "GY1: Genellikle arkadaşlarım arasında modayı geriden takip eden olarak bilinirim" ifadeleri analiz dışı bırakılmıştır. Yapılan modifikasyonlar sonrasında elde edilen değerlerin kabul edilebilir uyum değerleri içerisinde yer aldığı görülmüştür. Ayrıca ölçeklerin güvenilirlik ve geçerliliğini değerlendirmek için yapı güvenirliliği ve ortalama açıklanan varyans değerleri hesaplanmıştır. Bu hesaplamalar sonucunda; yapı güvenirlik değerlerinin, statü tüketimi 0.86 , tüketici ilgilenimi 0.85 , tüketici yenilikçiliği 0.91 , marka bağl1lı̆̆ 0.93 ve fiyat duyarlılığı 0.92 olduğu tespit edilmiştir. Ortalama açıklanan varyans değerlerinin ise, statü tüketimi 0.58 , tüketici ilgilenimi 0.62 , tüketici yenilikçiliği 0.61 , marka bağlllığ 0.59 ve fiyat duyarlılığı 0.64 olduğu görülmüştür.

Sonuç olarak doğrulayıcı faktör analizi sonucunda, statü tüketimi 4, tüketici ilgilenimi 2, tüketici yenilikçiliği 6, marka bağlılığı 4, fiyat duyarlılığından 5 olmak üzere toplam 5 değişken ve 21 ifadenin yapısal eşitlik modelleme analizinde kullanılmaya karar verilmiştir.

\section{Araştırma Modelinin Test Edilmesi}

Araştırma modelinde yer alan statü tüketiminin tüketici ilgilenimi, tüketici yenilikçiliği ve marka bağlılığına ve bunların fiyat duyarlılığına etkisini belirlemek için Yapısal Eşitlik Modeli (path analizi) kullanılmıştır. Path analizinden elde edilen ilk sonuçlara göre model uyum indeks değerlerinin kabul edilebilir sınırlar içerisinde yer almadığg görülmüştür. Değerlerin kabul edilebilir sınırlar içerisinde yer almadığının görülmesi üzerine öncelikle değişkeler arasındaki t değerleri incelenmiştir. Bu inceleme sonucunda tüketici ilgileniminin fiyat duyarlılı̆̆ ile tüketici ilgileniminin tüketici yenilikçiliği arasındaki t değerlerinin 1.14 ve 0.87 olduğunun görülmesi üzerine $\mathrm{H}_{2}$ ve $\mathrm{H}_{3}$ hipotezleri reddedilmiştir. Uyum değerlerinin istenilen seviyede olmamasından dolayı Ki-kare üzerinde en fazla modifikasyon öneren, statü tüketiminden "ST2: Statümü gösteriyor diye bir giysi satın almam”, tüketici yenilikçiliğinden “GY2: Arkadaşlarımla

\footnotetext{
2 Mükemmel Uyum Değerleri: $0 \leq \chi^{2} \leq 2 \mathrm{df}, 0.05<\mathrm{p} \leq 1.00,0 \leq \chi^{2} / \mathrm{df} \leq 2,0 \leq \mathrm{RMSEA} \leq 0.05,0 \leq \mathrm{SRMR} \leq 0.05,0.95 \leq \mathrm{NFI} \leq 1.00,0.97 \leq \mathrm{NNFI} \leq 1.00,0.97 \leq \mathrm{CFI} \leq 1.00$, $0.95 \leq \mathrm{GFI} \leq 1.00,0.90 \leq \mathrm{AGFI} \leq 1.00,0.95 \leq \mathrm{IFI} \leq 1.00$ (Schermelleh-Engel vd., 2003, s.52).

Kabul Edilebilir Uyum Değerleri: $2 \mathrm{df} \leq \chi^{2} \leq 3 \mathrm{df}, 0.01 \leq \mathrm{p} \leq 0.05,2 \leq \chi^{2} / \mathrm{df} \leq 3,0.05 \leq \mathrm{RMSEA} \leq 0.08,0.05 \leq \mathrm{SRMR} \leq 0.10,0.90 \leq \mathrm{NFI} \leq 0.95,0.95 \leq \mathrm{NNFI} \leq 0.97$, $0.95 \leq \mathrm{CFI} \leq 0.97,0.90 \leq \mathrm{GFI} \leq 0.95,0.85 \leq \mathrm{AGFI} \leq 0.90,0.90 \leq \mathrm{IFI} \leq 0.95$ (Schermelleh-Engel vd., 2003, s.52).
} 
karşılaştıııldığında son moda giysileri daha az satın alırım" ile "GY7: Yeni moda giysiyi görmemiş olsam bile satın alma isteği duyarım" ve fiyat duyarlılığından "GH2: Fiyatının yüksek olduğunu düşündüğüm giysiyi satın almaya daha az istek duyarım” ifadeleri modelden çıkarılmış ve modelin uyum değerlerinin; $\operatorname{Ki}-\operatorname{kare}\left(\chi^{2}\right)=369.06$, p değeri $=0.211$, serbestlik derecesi $(\mathrm{sd})=193, \chi^{2} / \mathrm{sd}=1.91, \mathrm{RMSEA}=0.063, \mathrm{SRMR}=0.051, \mathrm{NFI}=0.94, \mathrm{NNFI}=0.96, \mathrm{CFI}=$ $0.95, \mathrm{GFI}=0.96, \mathrm{AGFI}=0.91$ ve IFI=0.95’e sahip olduğu görülmüştür. Analiz sonucunda modelde yer kalan değişkenlere ait ifadelerin ortalama, standart sapma, $t$ değerleri, standart katsayıları, $\mathrm{R}^{2}$ ve hata varyansları Tablo 2'de gösterilmiş̧tir. 
Tablo 2. Araştırma Modelinde Yer Alan Değişkenlere Ait ifadelerin Aritmatik Ortalama, Standart Sapma, $t$ değeri, Standart Katsayı, $R^{2}$ ve Hata Varyansları

\begin{tabular}{|c|c|c|c|c|c|c|}
\hline Değişkenler ve ifadeleri & $\begin{array}{l}\text { Aritmetik } \\
\text { Ortalama }\end{array}$ & $\begin{array}{l}\text { Standart } \\
\text { Sapma }\end{array}$ & t değeri & $\begin{array}{l}\text { Standart } \\
\text { Katsayılar }\end{array}$ & $\mathbf{R}^{2}$ & $\begin{array}{c}\text { Hata } \\
\text { Varyansı }\end{array}$ \\
\hline \multicolumn{7}{|l|}{ Statü Tüketimi-ST } \\
\hline $\begin{array}{l}\text { ST1: Statümü gösteren giysiye daha fazla } \\
\text { öderim. }\end{array}$ & 4.02 & 084 & 21.34 & 0.60 & $\begin{array}{c}0.7 \\
4\end{array}$ & 0.18 \\
\hline $\begin{array}{l}\text { ST3: Statüm ile ilgili yeni giysilere ilgi } \\
\text { duyarım. }\end{array}$ & 3.76 & 1.00 & 22.47 & 0.58 & $\begin{array}{c}0.7 \\
1\end{array}$ & 0.20 \\
\hline $\begin{array}{l}\text { ST4: Farklılığımı gösteren giysi benim için } \\
\text { daha değerlidir. }\end{array}$ & 4.09 & 0.73 & 13.09 & 0.81 & $\begin{array}{c}0.8 \\
6\end{array}$ & 0.14 \\
\hline \multicolumn{7}{|l|}{ Tüketici İlgilenimi-GG } \\
\hline GG1: Giyime oldukça ilgiliyim. & 3.99 & 1.02 & 17.85 & 0.67 & $\begin{array}{c}0.9 \\
1\end{array}$ & 0.12 \\
\hline GG2: Giyim benim için çok önemlidir. & 4.05 & 0.95 & 18.01 & 0.66 & $\begin{array}{c}0.9 \\
2\end{array}$ & 0.10 \\
\hline Değişkenler ve ífadeleri & $\begin{array}{c}\text { AritmatikO } \\
\text { talama }\end{array}$ & $\begin{array}{l}\text { Standart } \\
\text { Sapma }\end{array}$ & t değeri & $\begin{array}{l}\text { Standart } \\
\text { Katsayılar }\end{array}$ & $\mathbf{R}^{2}$ & $\begin{array}{c}\text { Hata } \\
\text { Varyansı }\end{array}$ \\
\hline \multicolumn{7}{|l|}{ Tüketici Yenilikçiliği-GY } \\
\hline GY3: Son moda giysi trendlerini bilirim. & 3.91 & 0.79 & 11.88 & 0.71 & $\begin{array}{c}0.8 \\
5\end{array}$ & 0.12 \\
\hline GY4: Giyisi modacılarını takip ederim. & 3.87 & 0.88 & 21.63 & 0.55 & $\begin{array}{c}0.7 \\
4\end{array}$ & 0.26 \\
\hline $\begin{array}{l}\text { GY5: Arkadaşlarımdan önce yeni moda } \\
\text { hakkında bilgi edinirim. }\end{array}$ & 3.88 & 0.83 & 15.25 & 0.67 & $\begin{array}{c}0.8 \\
2\end{array}$ & 0.14 \\
\hline $\begin{array}{l}\text { GY6: Bir mağazaya yeni gelen kıyafetler satın } \\
\text { almak için ilgimi çeker. }\end{array}$ & 4.03 & 0.73 & 18.91 & 0.61 & $\begin{array}{c}0.9 \\
1\end{array}$ & 0.11 \\
\hline \multicolumn{7}{|l|}{ Marka Bağlılığı-GB } \\
\hline $\begin{array}{l}\text { GB1: Giysilerimi belirli markalardan satın } \\
\text { alırım. }\end{array}$ & 4.11 & 0.83 & 15.26 & 0.69 & $\begin{array}{c}0.5 \\
4\end{array}$ & 0.45 \\
\hline $\begin{array}{l}\text { GB2: Giysilerimi sürekli aynı markadan satın } \\
\text { alırım. }\end{array}$ & 4.02 & 0.79 & 19.56 & 0.51 & $\begin{array}{c}0.8 \\
7\end{array}$ & 0.15 \\
\hline $\begin{array}{l}\text { GB3: Satın almak istediğim markayı } \\
\text { buluncaya kadar giyim mağazalarını } \\
\text { dolaşırım. }\end{array}$ & 3.99 & 0.83 & 19.71 & 0.52 & $\begin{array}{c}0.8 \\
8\end{array}$ & 0.13 \\
\hline $\begin{array}{l}\text { GB4: Giysi satın alırken başka marka daha } \\
\text { uygun fiyatlı olsa bile ben gene de sürekli } \\
\text { satın aldığım markayı tercih ederim. }\end{array}$ & 4.05 & 0.99 & 23.08 & 0.47 & $\begin{array}{c}0.6 \\
1\end{array}$ & 0.28 \\
\hline \multicolumn{7}{|l|}{ Fiyat Duyarlılığı-GH } \\
\hline $\begin{array}{l}\text { GH1: Yeni moda giysilerin dahapahalı olması } \\
\text { benim için önemli değildir. }\end{array}$ & 4.01 & 0.82 & 11.09 & 0.61 & $\begin{array}{c}0.8 \\
8\end{array}$ & 0.18 \\
\hline $\begin{array}{l}\text { GH3: Yeni bir marka giysiyi satın almak için } \\
\text { daha fazla ödemeyi kabul ederim. }\end{array}$ & 3.92 & 0.88 & 9.88 & 0.84 & $\begin{array}{c}0.9 \\
1\end{array}$ & 0.11 \\
\hline $\begin{array}{l}\text { GH4: Yeni giysilerin fiyatı genellikle benim } \\
\text { için önemlidir. }\end{array}$ & 3.78 & 0.91 & 12.37 & 0.69 & $\begin{array}{c}0.8 \\
4\end{array}$ & 0.22 \\
\hline $\begin{array}{l}\text { GH5: Kaliteli giysiye gerçekten çok para } \\
\text { ödemeye değer. }\end{array}$ & 4.09 & 0.79 & 10.01 & 0.66 & 0.8 & 0.17 \\
\hline
\end{tabular}


Sonuç olarak, statü tüketiminin tüketici ilgileniminin tüketici yenilikçiliği ile marka bağlılığı ve tüketici yeniliğinide marka bağllı̆̆g üzerinde pozitif etkisi olduğu görülmüştür. Ancak, tüketici yeniliği ile marka bağlılığının ise fiyat duyarlılığı üzerinde negatif etkiye sahiptir. Bu durumda, $\mathrm{H}_{1}, \mathrm{H}_{4}, \mathrm{H}_{5}, \mathrm{H}_{6}, \mathrm{H}_{7}$ ve $\mathrm{H}_{8}$ hipotezleri kabul edilmiştir. Araştırma modelinin ve hipotezlerinin özet bilgileri aşağıdaki Tablo 3’de sunulmuştur.

Tablo 3. Modelde Yer Alan Değişkenler Arasındaki ilişkiler

\begin{tabular}{|c|c|c|c|c|}
\hline Hipotezler & t değeri & $\begin{array}{c}\text { Standart } \\
\text { Katsayılar }\end{array}$ & $\mathbf{R}^{\mathbf{2}}$ & $\begin{array}{c}\text { Hata } \\
\text { Varyansı }\end{array}$ \\
\hline $\mathrm{H}_{1}$ : Statü tüketimi tüketici ilgilenimini etkilemektedir. & 7.52 & 0.84 & 0.55 & 0.45 \\
\hline $\mathrm{H}_{2}$ : Tüketici ilgilenimi fiyat duyarlılığını etkilemektedir. & \multicolumn{4}{|c|}{ Hipotez red edildi. (t değeri = 1.14) } \\
\hline $\mathrm{H}_{3}$ : Tüketici ilgilenimi tüketici yenilikçiliğini etkilemektedir. & \multicolumn{4}{|c|}{ Hipotez red edildi. (t değeri $=0.87$ ) } \\
\hline $\mathrm{H}_{4}$ : Statü tüketimi tüketici yenilikçiliğini etkilemektedir. & 5.84 & 0.69 & 0.70 & 0.31 \\
\hline Hs: Tüketici yenilikçiliği fiyat duyarılığını etkilemektedir. & -3.19 & -0.20 & 0.78 & 0.29 \\
\hline H6: Tüketici Yenilikçiliği marka bağııı̆̆ını etkilemektedir. & 2.73 & 0.81 & 0.61 & 0.36 \\
\hline H7: Statü tüketimi marka bağlıı̆ı̆ını etkilemektedir. & 6.72 & 0.77 & 0.82 & 0.24 \\
\hline H8: Marka bağlıı̆ı̆ı fiyat duyarlııı̆ını etkilemektedir. & -4.09 & -0.21 & 0.49 & 0.52 \\
\hline
\end{tabular}

\section{Sonuç ve Tartışma}

Statü tüketiminin fiyat duyarlılığı üzerindeki etkisini belirlemek amacıyla Uşak il merkezinde ikamet eden devlet memurları üzerinde yapılan çalışmada aşağıdaki sonuçlar elde edilmiştir:

- Ankete cevap veren tüketicilerin çoğunluğunun 28-37 yaş aralığında, lisans mezunu, evli, kadın, aylık gelirinin 2601-3900 TL arasında olduğu tespit edilmiştir. Çalışılan bakanlık olarak ilk sırada Milli Eğitim Bakanlığı ikinci sırada ise Sağlık Bakanlığı gelmektedir.

- Öncelikle çalışmada kullanılan statü tüketimi, tüketici ilgilenimi, tüketici yenilikçiliği, marka bağlılığı ve fiyat duyarlılığı ölçeklerinin güvenilirlik katsayıları incelenmiş ve değerlerin 0.788 ve 0.834 ile yüksek seviyede olduğu tespit edilmiştir. Daha sonra bu ölçeklerin örnekleme uygunluğu için doğrulayıcı faktör analizi yapılmış ve statü tüketiminden 4 , tüketici ilgileniminden 2, tüketici yeniliğinden 6 , marka bağlılığından 4 ve fiyat duyarlılığından 5 ifade yapısal eşitlik modellemesi analizinde kullanılmıştır.

- Borgogno vd. (2015) çalışmalarında statüye önem veren tüketicilerin fiyatı düşük ve statülerinin göstergesi olmayan ürünleri tercih etmedikleri sonucuna varmışlardır. Flynn vd. (2016) ise tükecinin toplum içersinde statüsünün göstergesi olan ürünler hakkında bilgili olduklarını ve bu ürünleri satın alırken daha dikkatli olduklarını belirtmişlerdir. $\mathrm{Bu}$ çalışmada tüketiciler için statüsülerini gösteren ürünlerin daha değerli ve bu bağlamda bunlara daha fazla ödeyebilecekleri ve ilgilenim düzeylerinin yüksek olduğunu görülmüştür. Borgogno vd. (2015) ve Flynn vd. (2016) yaptıklarına benzer sonuç elde edilmiş yani statü tüketiminin tüketici ilgilenimini etkilediği tespit edilmiştir. Ramirez Goldsmith (2009), tüketicilerin statü göstergesi olan ürünlere ilgileniminin artması ile birlikte moda ve yeniliğin düşük fiyata göre etkisinin daha fazla 
olduğunu tespit etmelerine rağmen bu çalı̧̧mada tüketici ilgileniminin fiyat duyarllılı̆ üzerinede etkisinin olmadığı belirlenmiştir. Benzer şekilde tüketici ilgileniminin de tüketici yenilikçiliğini etkilemediği bulunmuştur.

- Mishra (2015) yeni ürünleri satın alanların, harcanabilir gelirlerinin yüksek ve diğerlerinden farklı olmak istediklerini belirtmektedir. Naehyun vd. (2016), yeni ve farklı ürünleri satın alanların sosyal durumlarının yüksek olduğu sonucuna varmışlarıdır. u yüksek olanların yeni ve farklı ürünleri satın aldıkları sonucuna varmışlarıdır. Benzer sonuçlara yakın sonuçlar bu çalışmada da elde edilmiştir. Statü tüketiminin, modayı takip eden ve arkadaşlarından önce yenilikler hakkında bilgili olan tüketicilerin satın alımlarında etkili olduğu tespit edilmiştir.

- Wingfield (2005) video oyun kullanıcıları, Munnukka (2005) mobil hizmet sektöründe ve Hussain ve Rashidi (2015) restoran hizmetleri alanında yaptıkları çalışmalarda yenilik ile fiyat duyarlılığı arasında negatif ilişkiler tespit edilmiştir. Giyim satın alımında statülerine uygun alısveriş yapan tüketicilerinde üzerinda yapılan bu çalışmada yeni ve moda olan ürünlerin için yüksek fiyatın önemli olmadığı sonucu elde edilmişltir. Yapılan teorik araştırmada tüketici yenilikçiliği ve statü tüketiminin marka bağlllığını etkilediği bulunmuştur. Benzer sonuçlar bu çalışmada da elde edilmiştir.

- Wilson (2006) denim ürün grubunda yaptı̆̆ ç̧alışmada üniversite öğrencilerinin marka bağlllı̆̆1 ve fiyat duyarlılığı arasında negatif korelasyon söz konusu olduğunu vurgulamıştır. Lau vd. (2006) giyim sektöründe gençler üzerinde yaptığı çalışmada, marka sadakati ile fiyat duyarllı̆ğı arasında negatif ilişki olduğunu bildirmiş ve fiyat odaklı satın alımlarını gerçekleştiren tüketici için markalar arasında farkın olmadığını belirtmiştir. Statü tüketimine önem verenler üzerinde yapılan bu çalışmada ise marka bağıllığı ile fiyat duyarlılığı arasında negatif ilişki tespit edilmiştir. Diğer bir ifade ile marka sadakati olan tüketicinin satın alımlarında ürünün fiyatına dikkat etmediği söylenebilir.

Araştırma sonuçlarına göre giyim sektöründeki üretici ve aracı işletmelere şu önerilerde bulunulabilir;

- Çalışmanın amacı statü tüketiminin fiyat duyarllıı̆̆ı üzerindeki etkisini anlamak ve bu ilişkinin nasıl gerçekleştiğine odaklanmaktır. Ayrıca statüye duyulan arzunun tüketicilerin daha fazla ödemesine neden olan sebeplerin derinlemesine incelemektir. Konu hakkında yapılan önceki çalışmaların sonuçlarına göre statüsüne önem veren ve bunu göstermek isteyen tüketiciler için ürün katılımı, yenilikçilik ve marka bağlllı̆̆ olmak üzere üç tüketici karakteristiğininde fiyat duyarlllığına aracılık ettiğini göstermiştir. İçgüdüsel alışveriş ve çevresel faktörlerinde statü tüketimi araştırmalarında fiyata olan etkisi incelenebilir.

- Statü tüketimi kendileri için öneli olan tükaticilerin giysi ürün ilgileniminin yüksek olduğu belirlenmiştir. Ürün reklam ve tanıtımında özellikle statüyü vurgulayan reklam karakterlerinin ve temalarının kullanılması ürüne olan ilginin artmasına yardımcı olabilir. Tutundurma çabalarında ürünün sağladığı farklı olma duygusununda öne çıarılması faydalı olabilir. 
- Statü tüketimine önem verenlerin moda odaklı olduğu görülmüştür. Moda konusunda yayın yapan medya araçlarında sosyal konum ve statü simgelerin kullanılmasının marka ve ürünün tanınırlığı açısından yararlı olabilir.

- Statü tüketimi ve fiyat duyarlılı̆̆ı arasında yapılan çalışmaların giyim sektöründe yoğunlaştığ1 görülmektedir. İleride elektronik, iletişim, otomotiv sektörlerinde de benzer çalışmaların yapılmasının konunun daha iyi anlaşılmasına katkı sağlayabilir.

\section{Kaynakça}

Aaker, D. A. (1991). Managing Band Equity, New York: Free.

Alves, H., Ferreira, J. J. \& Fernandes, C. I. (2016). Customer's operant resources effects on cocreation activities. Journal of Innovation and Knowledge, 1, 69-80.

Amaldoss, W. \& Jain, S. (2005). Conspicuous consumption and sophisticated thinking. Management Science, 51(10), 1449-1466.

Aslay, F., Ünal, S. \& Akbulut, Ö. (2013). Materyalizmin statü tüketimi üzerindeki etkisini belirlemeye yönelik bir araştırma. Atatürk Üniversitesi İktisadi ve İdari Bilimler Dergisi, 27(2), 43-62.

Assael, H. (2004). Consumer Behavior: A Strategic Approach, Boston: Houghton Mifflin.

Barnett, J. M. (2005). Shopping for Gucci on Canal Street: Reflections on status consumption, intellectual property and the incentive thesis. Virginia Law Review, 91(6), 1381-1423.

Bartels, J. \& Reinders, M. J. (2011). Consumer innovativeness and its correlates: A propositional inventory for future research. Journal of Business Research, 64(6), 601-609.

Beatty, S. E. \& Kahle, L. R. (1988). Alternative hierarchies of the attitude-behavior relationship: The impact of brand commitment and habit. Journal of the Academy of Marketing Science, 16(Summer), 1-10.

Bin, G. (2013). A reasoned action perspective of user innovation: Model and empirical test. Industrial Marketing Management, 42(4), 608-619.

Borgogno, M., Favotto, S., Corazzin, M., Cardello, A. V. \& Piasentier, E. (2015). The role of product familiarity and consumer involvement on liking and perceptions of fresh meat. Food Quality and Preference, 44, 139-147.

Brockhoff, K. (2003). Customers' perspectives of involvement in new product development. International Journal of Technology Management, 26, 464-481.

Chao, A. \& Schor, J.B. (1998). Empirical tests of status consumption: Evidence from women's cosmetics. Journal of Economic Psychology, 19(1), 107-131.

Charles, K.K., Hurst, E. \& Roussanov, N. (2009). Conspicuous consumption and race. Quarterly Journal of Economics, 124(2), 425-467. 
Chen, J. \& Kim, S. (2013). A comparison of Chinese consumers' intentions to purchase luxury fashion brands for self-use and for gifts. Journal of International Consumer Marketing, 25, 29-44.

Clark, R., Zboja, J. \& Goldsmith, R. (2007). Status consumption and rolerelaxed consumption: a tale of two retail consumers. Journal of Retailing and Consumer Services, 14, 45-59.

Coopers, P. W. (2012). South African Retail and Consumer Products Outlook 2012-2016. PWC, South Africa.

Cronje, A., Jacobs, B. \& Retief, A. (2016). Black urban consumers' status consumption of clothing brands in the emerging South African market. International Journal of Consumer Studies, 40, 754-764.

Dmitrovic, T., Vida, I. \& Reardon, J. (2009). Purchase behavior in favor of domestic products in the Western Balkans. International Business Review, 18(5), 523-535.

Dubois, D., Rucker, D. D. \& Galinsky, A. D. (2012). Super size me: Product size as a signal of status. Journal of Consumer Research, 38(6), 1047-1062.

Eastman, J. K., Goldsmith, R. E. \& Flynn, L. R. (1999). Status consumption in consumer behavior: Scale development and validation. Journal of Marketing Theory and Practice, $7(3), 41-51$.

Eastman, J. K. \& Liu, J. (2012). The impact of generational cohorts on status consumption: an exploratory look at generational cohort and demographics on status consumption. Journal of Consumer Marketing, 29, 93-102.

Eastman, J. K. ve Eastman, K. L. (2015). Conceptualizing a model of status consumption theory: An exploration of the antecedents and consequences of the motivation to consume for status. Psychology \& Marketing, 33(9): 761-776.

Flynn, L. R., Goldsmith, R. E. \& Kim, W. M. (2000). A cross-cultural validation of three new marketing scales for fashion research: Involvement, opinion seeking and knowledge. Journal of Fashion Marketing and Management, 4(2), 110-120.

Flynn, L. R., Goldsmith, R. E. \& Pollitte, W. (2016). Materialism, status consumption and market involved consumers. Psychology \& Marketing, 33(9), 761-776.

Fournier, S. (1998). Consumers and their brands: Developing relationship theory in consumer research. Journal of Consumer Research, 24(4), 343-373.

Gabriel, Y. \& Lang, T. (2006). The Unmanageable Consumer, (2. Baskı), Thousand Oaks, CA: Sage.

Gao, H., Winterich, K. P. \& Zhang, Y. (2016). All that glitters is not gold: How others' status influences the effect of power distance belief on status consumption. Journal OfConsumer Research, 43, 265-281.

Gardyn, R. (2002). Oh, the good life. American Demographics, 24(10), 30-35.

Goldsmith, R. E. \& Hofacker, C. F. (1991). Measuring consumer innovativeness. Journal of the Academy of Marketing Science, 19(3), 209-221. 
Goldsmith, R. E., Flynn, L. R. \& Eastman, J. K. (1996), Status consumption and fashion behavior: An exploratory study. in Proceedings of the Association of Marketing Theory and Practice, 5, 309-316.

Goldsmith, R. E. \& Newell, S. J. (1997). Innovativeness and price sensitivity: Managerial, theoretical and methodological issues. Journal of Product and Brand Management, 6(3), 163-174.

Goldsmith, R. E., Flynn, L. R. \& Kim, D. (2010). Status consumption and price sensitivity. Journal of Marketing Theory and Practice, 18(4), 323-338.

Han, Y. J., Nunes, J. C. \& Dreze, X. (2010). Signaling status with luxury goods: The role of brand prominence. Journal of Marketing, 74, 15-30.

Heffetz, O. (2011). A test of conspicuous consumption: visibility and income elasticities. Review of Economics and Statistics, 93, 1101-1117.

Hong, J. C, Lin, P. H. \& Hsieh, P. C. (2016). The effect of consumer innovativeness on perceived value and continuance intention to use smartwatch. Computers in Human Behavior, 67, 264-272.

Hussain, S. \& Rashidi, M. Z. (2015). Consumer innovativeness leading to innovation adoption. Pakistan Business Review, 17(3), 562-580.

Iyer, R., Eastman, J. K., Sharma, R. W. \& Eastman, K. L. (2017). The impact of cognitive age on materialism, status consumption and loyalty proneness on the Indian elderly. The Marketing Management Journal, 27(1), 48-62.

İslamoğlu, A. H. \& Alnıaçı, Ü. (2013). Sosyal Bilimlerde Araştırma Yöntemleri, İstanbul: Beta.

Kotler, P. (2000). Pazarlama Yönetimi. Nejat Muallimoğlu (Çev.). İstanbul: Beta.

Kwon, Y. \& Kwon, K. (2013). Cultural omnivores' consumption: strategic and inclusively exclusive. International Journal of Marketing Studies, 5, 118-127.

Lau, M. M., Chang, M. T., Moon, K. L. \& Liu, W.S. (2006). The brand loyalty of sportswear in Hong Kong. Journal of Textile and Apparel, Technology and Management, 5(1), 1-13.

Lertwannawit, A. ve R. Mandhachitara (2012). Interpersonal effects on fashion consciousness and status consumption moderated by materialism in metropolitan men. Journal of Business Research, 65, 1408-1416.

Lin, M. J. J., Tu, Y. C., Chen, D. C., \& Huang, C. H. (2013). Customer participation and new product development outcomes: The moderating role of product innovativeness. Journal of Management \& Organization, 19, 314-337.

Mann, B. J. S. \& Sahni, S. K. (2015). Exploring the drivers of status consumption for the wedding occasion. International Journal of Market Research, 57(2), 179-202.

Minton, E. A., Kahle, L. R., Jiuan, T. S. \& Tambyah, S. K. (2016). Addressing criticisms of global religion research: A consumption-based exploration of status and materialism, sustainability and volunteering behavior. Journal for the Scientific Study of Religion, 55(2), 365-383. 
Mishra, A. A. (2015). Consumer innovativeness and consumer decision styles: a confirmatory and segmentation analysis. The International Review of Retail, Distribution and Consumer Research, 25(1), 35-54.

Mittal, B. \& Lee, M. S. (1989). A causal model of consumer involvement. Journal of Economic Psychology, 10(3), 363-389.

Morton, C., Anable, J. \& Nelson, J. D. (2016). Exploring consumer preferences towards electric vehicles: The influence of consumer innovativeness. Research in Transportation Business \& Management, 18, 18-28.

Mullarkey, G. W. (2001). The influence of brands in the fashion purchasing process. University of Auckland Business Review, 3(1), 56-71.

Munnukka, J. (2005). Dynamics of price sensitivity among mobile service customers. Journal of Product and Brand Management, 14(1), 65-73.

Naehyun, J., Line, N. D \& Merkebu, J. (2016). Examining the impact of consumer innovativeness and innovative restaurant image in upscale restaurants. Cornell Hospitality Quarterly, 57(3), 268-281.

Nelissen, R. M. A. \& Meijers, R. M. A. (2011). Social benefits of luxury brands as costly signals of wealth and status. Evolution and Human Behaviour, 32, 343-355.

O’Cass, A. \& Frost, H. (2002). Status brands: Examining the effects of non-product-related brand associations on status and conspicuous consumption. Journal of Product and Brand Management, 11(2), 67-88.

O'Cass, A. \& McEwen, H. (2004). Exploring consumer status and conspicuous consumption. Journal of Consumer Behaviour, 4, 25-39.

Park, H. J. \& Rabolt, N. J. (2006). Brand loyalty and price sensitivity: Moderating effect of fashion innovativeness. paper presented at the International Textile and Apparel Association, San Antonio, TX, November 1-6.

Phau, I. \& Cheong, E. (2009). How young adult consumers evaluate diffusion brands: Effects of brand loyalty and status consumption. Journal of International Consumer Marketing, 21, 109-123.

Rahbariana, H. \& Meshkanib, F. A. (2014). Consumer involvement profiles: An application of consumer involvement in mobile industry. Management Science Letters, 4, 617-620.

Ramirez, E. \& Goldsmith, R. E. (2009). Some antecedents of price sensitivity. Journal of Marketing Theory and Practice, 17(3), 199-213.

Raskovic, M., Ding, Z., Skare, V., Dosen, D. O. \& Zabkar, V. (2015). Comparing consumer innovativeness and ethnocentrism of young-adult consumers. Journal of Business Research, 69, 3682-3686.

Roehrich, G. (2004). Consumer innovativeness: Concepts and measurements. Journal of Business Research, 57, 671-677. 
Schermelleh-Engel, K., Moosbrugger, H. \& Müler, H. (2003). Evaluating the fit of structural equation models: Tests of significance and descriptive goodness-of-fiteasures. Methods of Psychological Research, 8, 23-74.

Schimpfossl, E. (2014). Russia's social upper class: from ostentation to culturedness. British Journal of Sociology, 64, 63-81.

Segal, B. \& Podoshen, J. (2013). An examination of materialism, conspicuous consumption and gender differences. International Journal of Consumer Studies, 37, 189-198.

Shukla, P. (2010). Status consumption in cross-national context. Sociopsychological, brand and situational antecedents. International Marketing Review, 27, 108-129.

Sundie, J., Griskevicius, V., Vohs, K., Kendrick, D., Tybur, J. \& Beal, D. (2011). Peacocks, Porches and Thorstein Veblen: conspicuous consumption as a sexual signalling system. Journal of Personality and Social Psychology, 100, 664-680.

Tellis, G. J., Yin, E. \& Bell, S. (2009). Global consumer innovativeness: Cross-country differences and demographic commonalities. Journal of International Marketing, 17(2), $1-22$.

Tsai, S. (2005). Impact of personal orientation on luxury-brand purchase value: An international investigation. International Journal of Market Research, 47(4), 429-454.

Trigg, A. (2001). Veblen, Bourdieu, and conspicuous consumption. Journal of Economic Issues, $35,99-115$.

Wang, Y. \& Griskevicus, V. (2014). Conspicuous consumption, relationships and rivals: Women's luxury products as signals to other women. Journal of Consumer Research, 40(February), 834-851.

Wetlaufer, S. (2001). The perfect paradox of star brands: An interview with bernard arnault of LVMH. Harvard Business Review, 79(9), 116-123.

Wilson, A. E. (2006). Brand loyalty as a moderator of the price sensitivity-heavy users relationship. Society for Marketing Advances, 104-107.

Wingfield, N. (2005). You have reached the next level. Wall Street Journal (November 11), W1.

Xie, X. \& Jia, Y. (2016). Consumer involvement in new product development: A case study from the online virtual community. Psychology\&Marketing, 33(12), 1187-1194.

Yun, W. \& Hira, C. (2012). The effect of fashion innovativeness on consumer's online apparel customization. International Journal of Organizational Innovation, 5(2), 263-83. 